\title{
Coatings of metal substrates assisted by laser radiation
}

\author{
H. Caudevilla ${ }^{(*)}$, A. Romo ${ }^{(*)}$, J.C. Domingo ${ }^{(*)}$, C. López ${ }^{(*)}$, J.C. Díez ${ }^{(*)}$, J.I. Peña ${ }^{(*)}$ and \\ G.F. de la Fuente ${ }^{(*)}$
}

\begin{abstract}
In this contribution, a new way of obtaining ceramic coatings is presented. This method uses precursor suspensions, settled on substrates and in-situ pyrolised with a laser. Different deposition techniques of the ceramic precursors have been tested in order to obtain a homogeneous distribution on the metal substrate before the laser treatment.
\end{abstract}

Keywords: Sol-Gel. Laser pyrolisis. Zirconia.

\section{Recubrimientos de diversos sustrátos asistidos por radiación láser}

\begin{abstract}
Resumen La combinación de recubrimientos utilizando disoluciones de precursores metálicos con la pirólisis asistida por láser, permite obtener una gran diversidad de recubrimientos sobre sustratos de muy distinta naturaleza. Se han realizado estudios, tanto con disoluciones poliméricas, como con disoluciones de tipo sol-gel y pastas obtenidas con técnicas similares, depositadas utilizando métodos convencionales de inmersión y atomización previa a la pirólisis asistida por láser, así como simultánea. En este trabajo se presenta un resumen de los resultados más significativos obtenidos en la realización de recubrimientos sobre sustratos metálicos y cerámicos.
\end{abstract}

Palabras clave: Sol-Gel. Pirólisis láser. Zirconia.

\section{EXTENDED ABSTRACT}

Protective ceramic coatings on metal substrates has been proposed as an ideal solution to improve significantly the life and efficiency of numerous components used in mechanical operation, where the wear effects and high working temperatures prevent the use of metal in a common state. There are several advanced techniques for ceramic coating deposition on metallic pieces, however, they pose experimental difficulties, such as low deposition rates or complexity, that impose severe limitations on their industrial scale-up.

Laser technology offers some advantages such as ease of operation, flexibility in atmosphere selection, adaptability to different configurations and easy integration into the industrial environment (1).

(*) Instituto de Ciencia de Materiales de Aragón. (C.S.I.C. Univ. de Zaragoza). Centro Politécnico Superior de Ingenieros. C/ María de Luna, 3. 50015-Zaragoza (España).
In this contribution, a new way of ceramic coating is presented (2). This method uses precursor suspensions, settled on substrates and in-situ pyrolised with a laser. Different deposition techniques of the ceramic precursors have been tested in order to obtain a homogeneous distribution on the metal substrate before the laser treatment.

Zirconia is a good thermal insulator with high toughness and thermal shock resistance even in severe environmental conditions. However, the martensitic transformation from the high temperature phase (cubic) to monoclinic (below $1170 \mathrm{C}$ ) can have a detrimental effect on zirconia coatings subjected to thermal treatments (3). However, cubic phase zirconia can be stabilized in a large temperature range by the addition of some oxides as $\mathrm{MgO}, \mathrm{CaO}$ or several rare earth oxides. Fully stabilized zirconia has a thermal expansion coefficient im the range $12-14 \times 10^{-6}\left(\mathrm{C}^{-1}\right)$, close to that of many metals, which is very useful to produce ceramic coatings. 

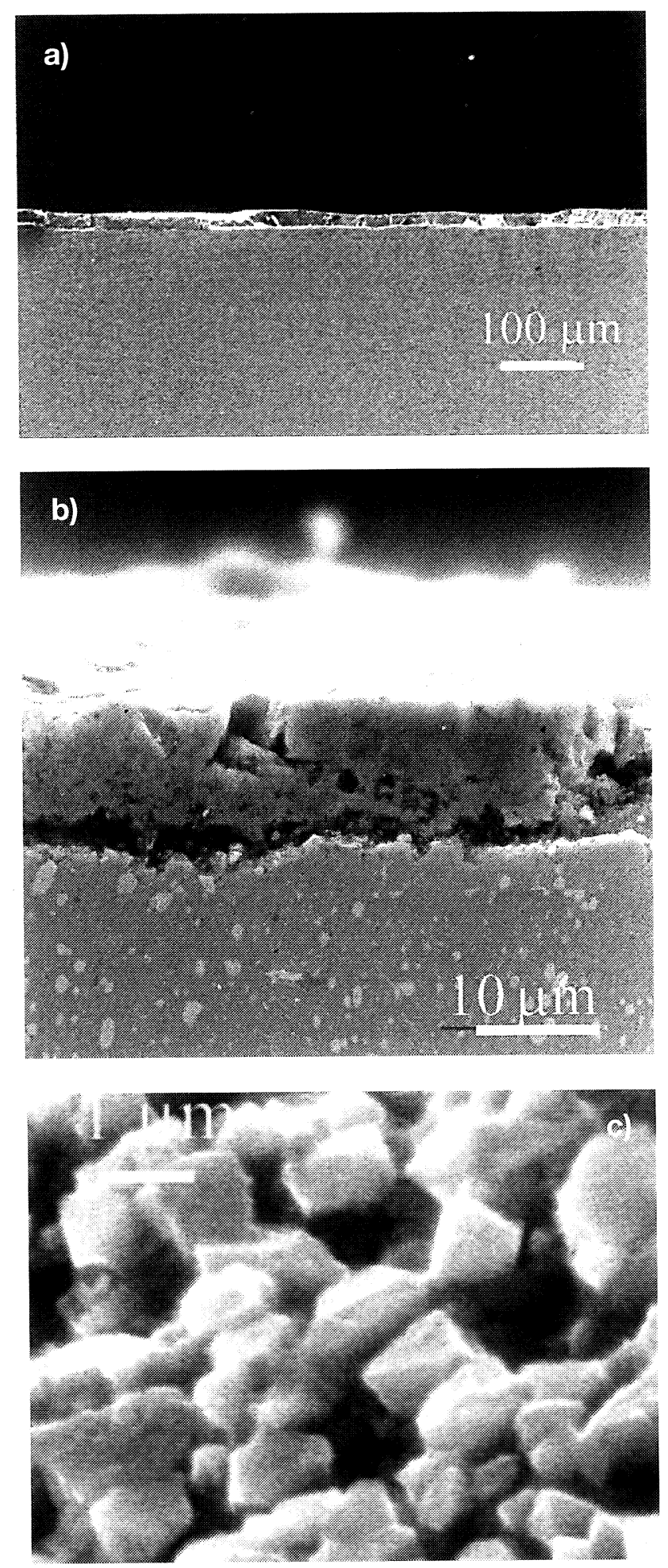

FIG. 1.- Micrografias SEM de $\mathrm{ZrO}_{2}-\mathrm{CaO}$ sobre acero $\mathrm{S} 600$ a distintos aumentos.

FIG. 1.- Several SEM micrographs of $\mathrm{ZrO}_{2}-\mathrm{CaO}$ on a $\mathbf{S 6 0 0}$ steel at different magnifications.
Most of the experiments were carried out in two different types of steels, namely high speed (S600) steel and plain carbon steel (C1016), in order to study the effect of the alloying elements in the process. In both cases it was possible make coatings of 20 to $30 \mu \mathrm{m}$ in thickness with a roughness of about $1 \mu \mathrm{m}$, depending on the treatment conditions, when zirconia is used as a protective coating.

Process parameters were adjusted to produce a dense film with good bonding with the metal substrate, without modifications in the latter.

We will also describe a new carburizing method assited by laser. In this process an homogeneous film of polymer is deposited onto the steel piece by dip coating and subsequently pyrolized using laser radiation (4).

\section{REFERENCIAS}

(1) Belforte, D. and Levitt, M. The Industrial Laser Handbook. Springer-Verlag. New York, 1992: 13-31.

(2) Domingo, J.C. Recubrimiento Cerámico de Aceros realizado con Radiación Láser, Proyecto Fin de Carrera, Universidad de Zaragoza, 1997.

(3) Claussen, N., Rühle, M. and Heuer, A.H. Advances in ceramics, vol. 12. Science and Technology of Zirconia. Sections IV and V. The American Ceramic Society Inc., 1984.

(4) Romo, A. Recubrimiento de Aceros con Polietilenimina y Tratamiento Térmico con Láser, Proyecto Fin de Carrera, Universidad de Zaragoza, 1996. 